\title{
Prevelance of Female Ejaculation in A Group of Egyptian Women
}

http://bjas.journals.ekb.eg

\section{I.Younis ${ }^{1}$,R.M.Salem ${ }^{2}$, R.M.Ramadan}

${ }^{1}$ Professor of Dermatology, Venereology and Andrology Dept., Faculty of Medicine, Benha Univ., Benha, Egypt

${ }^{2}$ Lecturerof Dermatology, Venereology and Andrology Dept., Faculty of Medicine, Benha Univ., Benha, Egypt

${ }^{3}$ (M.B.B.CH), Faculty of Medicine, Cairo Univ., Egypt

E-Mail:rtmagdi@hotmail.com

\section{Abstract}

Female genital secretions during sexual intercourse have been a matter of controversy for centuries.Ancient Chinese, Indian and Greek books contain phrases that strongly point to the occurrence of female ejaculation. Assess the prevalence of female ejaculation in a group of Egyptian women.Thetoolofthestudywasaself-reportquestionnairewhichwas designed by investigators. Theaimofthestudyandthedetailsofthequestionnairewereexplainedtothe womenbefore takingtheir informedconsent. The study was approved by the Ethics Committee of Human Research, Faculty of Medicine, Benha University.The number of women that participated and answered questionnaire in this study was 338.Among them,7.1\% onlyreported experiencing ejaculation when reaching orgasm. Female ejaculation is still a matter of debate which needs further studies.

Keywords:Ejaculation, squirting, Female genital cutting, Debate and women.

\section{Introduction}

Female ejaculation (squirting, orgasmic expulsions) is one of the most debatable subjects among the sexology community. Its existence, source and nature are, all, have their proponents and opponents. Part of the problem is that this area of female sexual function is very difficult to investigate. This is mainly because of the obvious problem of inability of investigators to attend female ejaculation in a considerable number of subjects [1] The current work is a trial to shed some light on this controversial subject.

\section{Historical background}

Female ejaculation has been known and described in important documents by intellectual leaders of both Eastern and Western cultures for more than 2,000 years [2]. Female ejaculation was a tradition in ancient cultures of China, India, Japan, and other areas in Asia and Africa. The Romans called these fluids liquor vitae and in ancient India they were called amrita (nectar of the gods) [3].

At china,An old Chinese poem "Amusement of heaven and earth," written by Bai Xingjian (775-826 A.D.) mentioned an area located at the anterior vaginal wall that is referred to as "milk fruit". It was believed that the red color of the mulberry fruit was the reason the author named this vaginal area, which produces whitish "milky" fluid (female ejaculate) [4].

"Secret Methods of the Plain Girl" is an old chinese book written sometime between 590 and 618 A.D. by $\mathrm{Su} \mathrm{Nu}$ Ching. In it, female ejaculation is described as "copious emissions" as follows: "Her vagina becomes moist and slippery, then the man should plunge into her very deeply. Finally copious emissions from her Inner Heart begin to exude outward "[5].

At India, The oldest documentation of female ejaculation in ancient Indian literature can be found in the 7th century A.D. described by Amaru "Occasionally the production of fluids is so profuse that a large towel has to be spread under the woman to prevent the bed sheets getting soiled". Female ejaculation was more than just scientific fact from ancient India, but also as a part of erotic literature [6].

Greek,Female semen was mentioned earlier in time by ancient Greek philosophers including Pythagoras (570-510 B.C.) who described it as a "Discharge" from the uterus which occurs in some women but not in others. It is found in those who are fair skinned and of a feminine type generally but not in those who are dark and of masculine appearance. The amount of this discharge when it occurs is sometimes on a different scale from the emission of semen and far exceeds it[7].

Arabic region, IbnSina was an 11th century arabian physician and philosopher .The main book done by IbnSina is called " $\mathrm{L}$ qanun Fi At Tibb" (Latin: "Canon medicinae"). IbnSina mentioned in this book that women ejaculate some kind of liquid with pleasure either during coitus or without any coitus. However, he believed that female ejaculate was hardly perceptible since the semen was sucked in by the womb's orifice. He stated, "women ejaculate their sperm in the neighborhood of the urethra" [8].

Galenic, The term "female prostate" used by William E. Horner (1793-1853 A.D.) an anatomist raises the question of whether he was aware of the function of prostatic tissue 
and the possibility of emission of female ejaculate [9].

Alexander Skene (1837-1900 A.D.) is credited as the first to describe what are now called Skene's glands. Skene identified small mucous glands located at and extending from the urethral meatus in an upward fashion beneath the mucous membrane in the muscular walls of the urethra. He precisely located the opening of their ducts on each side of the urethral meatus [8].

Recently were the first to analyze ejaculate from a woman and found a significant chemical dissimilarity (prostatic acid phosphatase, urea and creatinine) between urine and ejaculate [10].

Gräfenbergobserved women masturbating to orgasm, he noticed expulsion of fluids with orgasm out of the urethra "in gushes" and concluded this phenomenon had no lubricating significance since it appeared at the end of orgasm and not at the beginning of sexual stimulation. He said "In the cases observed by us, the fluid was examined and it had no urinary character. I am inclined to believe that 'urine' reported to be expelled during female orgasm is not urine, but only secretions of the intraurethral glands correlated with the erotogenic zone along the urethra in the anterior vaginal wall" [11].

\section{Female prostate}

The most profound and extensive research described the prostate of females being significantly smaller than the male prostate and lying within the wall of the urethra, while the male prostate surrounds the urethra [15].

The female prostate is one fourth to one fifth smaller (5.3 g vs. $23.7 \mathrm{~g}$ ) and contains a higher proportion of glandular and ductal components than the male prostate. It is unlikely that it can produce tens of milliliters of gushing fluid, considering that the average volume of male ejaculate is $3.2 \neg+1.4 \mathrm{ml}$ and the actual prostatic component constitutes a maximum of $25-30 \%$, or approximately $1 \mathrm{ml}$ [16].

The female prostate secretion contains a high concentration of PSA, prostatic-specific acid phosphatase,fructose, and glucose[17].

Despite this data, there is still controversial discussion. While some scientists still question the existence of the female prostate (G-spot). Modern technology allows visualization of the female prostate, such as the ultrasound and MRI that study of the anatomy of the female prostate[18].

In MRI studies, Wimpissinger found anatomical structures suggestive of the female prostate in 6 of 7 women. The average weight of the female adult prostate is 2.6-5.2 gm[19].

Its location is typically lateral in the distal half of the urethra, producing secretions to the urethral meatus [12].

Compared with the male prostate, there is a higher proportion of ducts and musculofibrous tissues than glands in the female prostate(Table1). It is not clear if the glands open into the distal urethra through single or multiple orifices, which is similar to the male prostate, or whether they lead to the sides of urethral meatus [21].Up to 20 ducts are found in the female prostate. The ducts are not visible on urethroscopy [19].

\section{Controversy about female ejaculation}

Scientific work on this essential part of female sexual function has been able to differentiate between female ejaculation, urinary incontinence and vaginal transudate [2].

Real female ejaculation is the secretion of an extremely scanty (few milliliters), milky fluid by the female prostate, which was described by de Graaf in 1762 and later described as Skene'sparaurethralglands[12].

Regarding site and nature of the female expelled fluid during and after the sexual stimulation we have main four types of fluid as follows:Vaginal lubrication, Female ejaculation , Squirting (gushing) and Coital incontinence

Zaviacic argued that female ejaculate is not urine, as it contains chemical components of female prostate secretions. However, he did concede that in some cases of stress incontinence, female ejaculate could be urine[13].

Schubach used a thin urethral catheter to distinguish the origins of gushing fluid at orgasm, thus draining the urinary bladder while avoiding compression of the meatuses of the female prostate ducts. In a study involving seven women, he collected $50-900 \mathrm{ml}$ of fluid containing less urea and creatinine and without the prostatic components of fructose and glucose during the massive orgasmic expulsions. In three cases and noted the simultaneous secretion of a small quantity of thick whitish fluid in the area of urethral meatus, which he considered to be a secretion of the female prostate [14].

\section{Types of vaginal fluids}

-Vaginal lubrication fluid

Lubrication fluid is an ultra-filtrate of blood plasma. Blood flow in the genital area is increased during sexual arousal and lubrication 
fluid from the vaginal venous plexus enters the vaginal lumen transvaginally[28].

The vaginal fluid may also contain peritoneal and follicular fluid, uterine fluid, cervical fluid, and secretions from Bartholin's and Skene's glands. The daily production is approximately 6 grams. Lubrication fluid is characterized by high potassium and low sodium concentrations compared with plasma and has an average $\mathrm{pH}$ of 4.7 (range:3.4-6.4) [22].

The mean vaginal discharge quantity is $1.5 \mathrm{~g} / 8 \mathrm{~h}$ (maximum at mid-cycle, $2.0 \mathrm{~g} / 8 \mathrm{~h}$ ) [29]. Insufficient lubrication is reported in 3$43 \%$ women and occurs most commonly after menopause [30]. Increased lubrication does not cause any problems and is considered a discharge rather than a gush, especially when a penis is inserted [21].

\section{-Squirting}

Squirting is the involuntary expulsion of a substantial amount of urine during sexual activity. Until recently, most orgasmic emissions have been erroneously called the Female Ejaculation [31].

Mechanism of squirting has not been so far completely explained and is based on only a few methodologically inadequate studies or empirical observations, which are however insufficiently described. This is due to the technical difficulty of exact measuring in the course of this phenomenon and also problematic sample collection[21].

Squirting could be related to high blood pressure, high glomerular filtration, or altered production of aldosterone at sexual arousal[14]. The concentration of the emitted fluid may be influenced by other factors, such as water intake, surrounding temperature, physical activity, metabolic condition, hormonal activity, overall health condition, and psychogenic aspects [12].

The fluid squirted would have a different composition from urine depending on the interval between the last void[14].

The pathophysiology by which urine becomes diluted with lower creatinine, urea, uric acid, and density compared with normal urine, during sexual arousal remains unknown. The volume of massive gushes (which could be recurring) usually ranges from 15 to $110 \mathrm{ml}$ (median, $60 \mathrm{ml}$ ), and the color is most frequently described as clear as water. The fluid at squirting was inaccurately attributed to the female prostate based on the concentrations of PSA and PAP, which were considered the main markers for differentiation. Moreover, the detection of PAP in the urine may be complicated, as the concentration is small and diagnostic kits primarily serve to determine the level of phosphatase in the blood and not in the urine [32].

Smaller volume of fluids may be expelled by the female prostate, vagina or Bartholin's glands . Larger volume could originate from the urinary bladder [31].

\section{- Coital incontinence}

Coital incontinence is manifested by an involuntary leakage of urine during sexual intercourse. Coital incontinence can be divided into penetration and orgasm types. The prevalence of coital incontinence in women with urinary incontinence (UI) ranges from 10 to $67 \%$. Compared with women with detrusor overactivity (DOA), women with stress urinary incontinence (SUI) more frequently report coital incontinence[33].

During sexual excitation (increased blood pressure, faster glomerular filtration, changes in hormonally conditioned reabsorption mechanisms in the kidneys), the bladder is filled more rapidly with less concentrated urine [14].

With the bladder's capacity (around 500 $\mathrm{mL}$ ), expulsions with an average volume of 60 $\mathrm{mL}$ during sexual stimulation may be repeated [2].

Coital incontinence is caused by various provocative moments, such as increased intraabdominal pressure, penile insertion, deep penetration, high arousal, orgasm, and clitoral stimulation[21].

It seems likely that it is not only DOA or increased mobility of the urethrovesical junction involved in orgasmic incontinence, but rather a combination of both [21].

In some cases, women with ejaculation orgasm can develop UI. Further, women with CI may also be capable of ejaculation orgasm, or both situations may be combined. There is controversy regarding the etiology and pathophysiology of orgasmic incontinence[34].

Although there has been much research regarding orgasmic expulsions and $\mathrm{CI}$, their exact pathophysiological mechanisms remain unknown. Future research directions include determining the actual prevalence and mechanisms of their origins[21].

Women with coital incontinence experience leakage of urine frequently and involuntarily during the day, thus, there is no problem with the identification of coital incontinence .Those women were able to recognize that urine is leaked during sexual activities, unlike women who are capable of squirting and do not consider the fluid to be urine [22]. Physiological signs of female arousal are 
sometimes mistaken for coital incontinence. Furthermore, while expulsion of fluid during sexual intercourse may signify a high level of arousal, it can also be a sign of urinary incontinence [21].

Detrusor contractions are likely responsible for these gushes, as there is no other muscle capable of such forceful contractions in this anatomical area. In contrast to women with coital incontinence, women with female ejaculation do not show any evidence of DOA on urodynamic studies, but does not exclude the possibility that orgasm may be a triggering moment of uninhibited detrusor contractions [35].

Women with ejaculation orgasm should be considered continent and those with CI should be provided with appropriate therapy depending on their urodynamic studies. The penetration form of $\mathrm{CI}$ is surgically treatable almost in $80 \%$ of cases and orgasmic incontinence may improve in $60 \%$ after adequate pharmacotherapy [36].

Biochemical analysis of female ejaculation revealed high concentrations of PSA, glucose, and fructose, whereas the fluid at squirting, unlike female ejaculation, has higher concentrations of uric acid, urea, creatinine, and sodium; has a substantially lower density; and contains practically no fructose or glucose. Biochemical differentiation of expelled fluids during orgasmic incontinence at coital incontinence and orgasm at squirting is more difficult to perform [22].

Differentiation based on biochemical markers characteristic of urine (uric acid, urea, creatinine, chloride, potassium) could be misleading; although some authors provided evidence of lower quantity of these markers at squirting, others found no differences (SQ is voided urine) [31].

Urodynamic examination may help differentiate orgasmic incontinence from female ejaculation or squirting. Continent women with ejaculation orgasm do not show high detrusor activity or any other abnormal urodynamic parameters . In contrast, incontinent women with CI always have pathological findings on urodynamic studies [37].

The ejaculate contains high levels of prostatic acid phosphatase, prostatic specific antigen, glucose, and fructose, but low levels of urea and creatinine. The chemical composition of healthy urine is the opposite of female ejaculate, so they are easily differentiated from each other [3].

Female ejaculation, squirting, and CI are three completely different phenomena. Understanding their mechanisms may help to differentiate them according to their manifestations, subjective feelings, and biochemical composition of the expelled fluid[31]. Decreasing PSA concentration is observed in the following: female ejaculate ,urine, squirting and vaginal secretion sequently[32].

\section{Theories against ejaculation}

One reasonable critique against the concept of female ejaculation is the volume of ejaculated fluid compared with the male ejaculate. The source of male seminal fluid is well known. The capacities of the seminal vesicles and the prostate gland correlate well with ejaculated volumes. It is hard to believe that the female paraurethral glands (female prostate) have the capacity to store volumes that account for female ejaculation. High flow rates have been proven for other human glands with a parenchymal morphology (salivary glands ) [2].

Used data from over 1000 women participating in their sex therapy programs and concluded that only a 'handful' of these women had reported a spurt of fluid at the moment of orgasm. 'Although it is clear that at least some women experience this ejaculationlike response, it should be realized that a number of these cases represent a condition called urinary stress incontinence in which urine is expelled from the urethra due to physical straining'[26].

studied 38 healthy women to investigate the hypothesis that female orgasm is associated with ejaculation. The study comprised electrovibration of the glans clitoris until orgasm with simultaneous recording of vaginal and uterine pressures as well as electromyography of corpus cavernous and ischiocavernosus and bulbocavernosus muscles. At orgasm, the electromyography of ischiocavernosus and bulbocavernosus muscles increased intermittently. Orgasm was not associated with the appearance of fluid coming out of the vagina or urethra[27].

\section{Impact of female ejaculation}

Women with ejaculation orgasm may be extremely excitable and continent, reporting strong feelings of satisfaction when ejaculating [36].

Squirting occurs during sexual stimulation of the clitoro-urethro-vaginal complex . Women and their partners consider squirting to be a positive phenomenon that improves their sexual life [22].

substantial challenge. Respondents were asked how large a wet spot on a fluffy bath towel would be when given a scale of common 
household objects. Three women reported a soda can to compact disc-sized wet spot after a typical ejaculation. Nine women reported substantially larger amounts of fluid. The majority of participants described releasing copious amounts of fluid. It 'soaked the bed' or 'sprayed the wall'. Acceptance of ejaculation as a part of their sexual response seemed to go hand in hand with having a system for dealing with it. Most commonly, participants kept a stack of towels by the bed. They mentioned using washable $3 \times 3 \mathrm{~cm}$ incontinence pads, waterproof mattress pads, and even traveling with large plastic lined pads[41].

Antimicrobial compounds, such as zinc that is found in seminal plasma, are similarly present in female ejaculate. The release of such antimicrobial compounds would confer a protective advantage, including a reduction in the incidence of urinary tract infections[42].

\section{Material and methods}

This study acrosssectionalstudyconducted on women attended the Dermatology and Andrology outpatient clinics at Benha University hospitals. Thetoolofthestudywasaself-

reportquestionnairewhichwas designed by the investigators.

Theaimofthestudyandthedetailsofthequestionna irewereexplainedtothe womenbefore takingtheir informedconsent. The study was approved by the Ethics Committee of Human Research, Faculty of Medicine, Benha University. Participants with any of the following conditions were excluded from the study:divorced, widowed,severely ill or pregnant women.Data were tabulated and analyzed using the suitable statistical tests.

\section{Results}

The study involved 338 married women of different ages and cultures withregular sexualrelation. Their age ranged between the 20 and 49 years. The demographic and basic data are displayed in Table (1).

Table (1) Demographic data ofparticipants.

\begin{tabular}{lc}
\hline Variable & $\begin{array}{c}\text { Studied group } \\
(\mathbf{n}=\mathbf{3 3 8})\end{array}$ \\
\cline { 2 - 2 } Female genital cutting: & $\mathbf{n}(\mathbf{\%})$ \\
\cline { 2 - 2 } positive & $197(58.3)$ \\
Negative & $141(41.7)$ \\
Educational level: & \\
Educated & $294(87)$ \\
Not educated & $44(13)$ \\
Place of residence: & \\
Urban & $283(83.8)$ \\
Rural & $55(16.2)$ \\
\hline
\end{tabular}

Among the 338 women included in this study, 24 women(7.1\%)only reported having ejaculation with orgasm Fig (1).

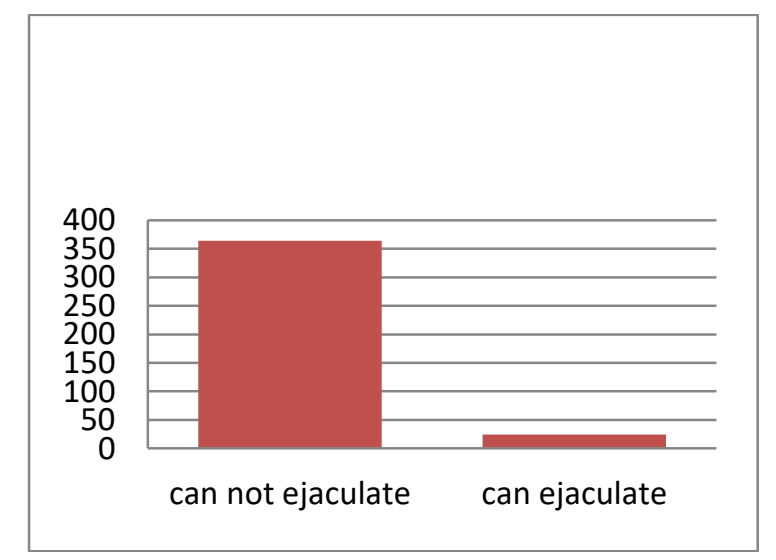

Fig (1) Percentage of women who reported the ability to ejaculate when reaching orgasm. 


\section{Discussion}

The current results showed that $58.3 \%$ of the participants were genitally cut. Previous studies of Elnashar and Abdelhady[46], Ibrahim [47] and Younis [50]reported a much higher percentage of genitally cut women in the studied samples $(75.8 \%, 71.7 \%$ and $89.2 \%$ respectively). This great reduction in the prevalence of genital cutting may be attributed to the increased awarenessamong the society, the fear of punishment by law and the high percentage ofhighly educated participants in the present sample.

The current study shows that $7.1 \%$ of the women only experience ejaculation. This agrees with Masters [45] who showed that only $4.7 \%$ of 300 women ejaculated and Kratochvi' [44] who found that orgasmic expulsions resembling male ejaculation were reported in $6 \%$ of his sample.

Bulloughet [48] reported that $54 \%$ of 227 women questioned reported ejaculation with orgasm. In the study of Davidson [49]39.5\% of the respondents reported having ever experienced ejaculation at the moment of orgasm, and the study by Darling [43] and Younis.[1] reported similar figures (40 and $40.2 \%$,respectively).

Women reported the need to urinate during G-spot stimulation. Reportedly, such physiological sensations result in some women suppressing their feelings of sexual arousal, fearing that urination may actually occur during stimulation of this sensitive area. Among the women studied by Darling [43], $39.5 \%$ of ejaculators and $14.1 \%$ of nonejaculators shared the belief that they had urinated during orgasm. Women reporting the need to urinate around the time of orgasm comprised $29.3 \%$ of women questioned in the study by Younis [1].

studied the subject of femaleejaculation in detail. They used a questionnaire distributedover the internet with 320 women of different agesand from different countries. The percentage of ejaculatorswas as follows: the frequency of ejaculation was 'a fewtimes a week' in $31.6 \%$, 'a few times a month' in $28.4 \%$, 'daily' in $19.4 \%$, and 'monthly or less frequent' in $20.6 \%$ [2].

reported ejaculate volume to range from 0.3 milliliter in $12.2 \%$ of women, 15 milliliters in $18.1 \%$, 60 milliliters in $29.1 \%$, 150milliliters in $15.3 \%$, and more than 150 milliliters in $25.3 \%$ of women. In this context the questionnaire listed a number of visual options for the participants such as tablespoons (15 milliliters) or 'a few drops' (0.3 milliliters) [2].

reported in their study, that most participants ejaculate at clitoral orgasm
(52.2\%). The aim of this specific question in their questionnaire was to establish whether ejaculation solely occurs upon stimulation of the anterior vaginal wall (the paraurethral sponge) or through the clitoral stimulation. [45].

\section{Conclusion}

Despite the presence of reports about female ejaculation since antiquity, the debate about its occurrence is still going on. A minority of women had the evidence that indicates that they really ejaculate.

\section{References}

[1] I. Younis and R.M. Salem, Female ejaculation: who is going to sleep on the wet side of the bed?.Hum Androl, Vol. 6, PP. 86-91, 2016.

[2] F.Wimpissinger,C. Springer and W.Stackl, International online survey: female ejaculation has a positive impact on women's and their partners' sexual lives. BJU International,vol 112 ,PP. 177$185,2013$.

[3] B. Whipple, Female Ejaculation, G Spot, A Spot, and Should We Be Looking for Spots?.Curr Sex Health Rep , Vol.7(2), PP. 59-62,2015.

[4] R. Pfister, Der Milchbaum und die Physiologie der weiblichenEjakulation. BemerkungenüberPapiermaulbeer-und FeigenbäumeimSüdenAltchinas.

AsiatischeStudien , Vol. 61 ,PP. 813844,2007.

[5] R. Chalker, The clitoral truth: The secret world at your fingertips. New York: Seven Stories Press, 2000

[6] J. Korda, S. Goldstein and F. Sommer, The history of female ejaculation. J Sex Med, Vol.7,PP.1965-1975,2010.

[7] I.M. Lonie, Hippocrates. The Hippocratic treatises, "On generation," “On the nature of the child," "Diseases IV": A commentary. Berlin: Walter de Gruyter,1981 .

[8] A.speer and L. Wegener ,wissenübergrenzen. Berlin:walter de gruyter,2006.

[9] G Dhom,Geschichte der Histopathologie.Berlin: Springer,2001.

[10]F. Addiego, E. Belzer, J. Comolli, W. Moger, J. Perry and B. Whipple, Female ejaculation: A case study. J Sex Res, Vol. 17,PP.13-16,1981.

[11]R. Gräfenberg , The role of urethra in female orgasm. Int JSexol, Vol. 3,PP.146, 1950.

[12]Z. Pastor and R. Chmel , Differential diagnostics of female sexual fluids: a 
narrative review. IntUrogynecol J,Vol.29(5),PP.621-629,2017.

[13] M. Zaviacic, A. Zaviacicova, I. Holoman and J. Molcan, Female urethral expulsions evoked by local digital stimulation of the G-spot: Differences in the response pattern. J Sex Res ,Vol. 24, PP.311318,1988 .

[14] G. Schubach, Urethral expulsions during sensual arousal and bladder catheterization in seven human females. EJ Hum Sex, ,Vol.4, PP.1-54, 2001.

[15] M. Zaviacic and R.J. Ablin, The G-spot. Am J ObstetGynecol ,Vol.187, PP. 519520, 2002.

[16] M. Zaviacic, M. Zajickova, J. Blazekova, L. Donarova, S. Stvrtina, M. Mikulecky, T. Zaviacic, K. Holoman, J. Breza, Weight, size, macroanatomy, and histology of the normal prostate in the adult human female: A minireview. J Histo tech ,Vol.23,PP.61-69, 2000.

[17] P. Dwyer, Skene's gland revisited: function, dysfunction and the $G$ spot. IntUrogynecol J ,Vol. 2,PP. 135-137, 2012.

[18] P. Foldes and O. Buisson, The clitoral complex: A dynamic sonographic study. J Sex Med,Vol. 6, PP.1223-1231, 2009.

[19] F. Wimpissinger, K. Stifter, W. Grin and W. Stackl ,The female prostate revisited: Perineal ultrasound and biochemical studies of female ejaculate. J Sex Med , Vol. 4, PP.1388-1393,2007.

[20] W. Dietrich, M. Susani, L. Stifter and A. Haitel, The human female prostateimmunohistochemical study with prostate-specific antigen, prostatespecific alkaline phosphatase, and androgen receptor and $3 \mathrm{D}$ remodeling. $\mathrm{J}$ Sex Med ,Vol. 8, PP.2816-2821, 2011.

[21] Z. Pastor, Female Ejaculation Orgasm vs. Coital Incontinence A Systematic Review. J Sex Med,Vol.10,PP.16821691,2013.

[22] Z. Pastor and R. Chmel , Differential diagnostics of female sexual fluids: a narrative review. IntUrogynecol J , Vol. 29(5),PP.621-629,2017.

[23] A. Burri, L. Cherkas and T. Spector , Genetic and environmental influences on self-reported G-spots in women: a twin study. J Sex Med ,Vol.7,PP.18421852,2010.

[24] F. De La Hozand L. Santiago, The Mythical G-Spot: Past, Present and Future.J Med Res ,vol 14,PP.44-51,2014.

[25] V. Puppo, The definition of "have sex" must be unique.J
PediatrAdolescGynecol,Vol. 24,PP.266271, 2011.

[26] W. Masters and V. Johnson, Human sexual response. Boston: Little, Brown, 1966.

[27] . A. Shafik, I. Shafik, O. El Sibai, A. Shafik, An electrophysiologic study of female ejaculation. J Sex Marital Ther, vol 35, PP.337-346,2009.

[28] R. Levin, S. Both, J. Georgiadis, T. Kukkonen, K. Park and C. Yang, The physiology of female sexual function and the pathophysiology of female sexual dysfunction (committee 13A). J Sex Med,Vol.13,PP.733-759,2016.

[29] M. Godley , Quantitation of vaginal discharge in healthy volunteers. BJOG, Vol.92,PP.739-742, 1985.

[30] R. Hayes, C. Bennett, L. Dennerstein, J. Taffe and C. Fairley, Are aspects of study design associated with the reported prevalence of female sexual difficulties? FertilSteril ,Vol.90, PP.497-505,2008.

[31] S. Salama, F. Boitrelle, A. Gauquelin, L. Malagrida, N. Thiounn and P. Desvaux , Nature and origin of Bsquirting in female sexuality. J Sex Med,Vol.12, PP.661666,2015.

[32] A. Rubio-Casillas and E. Jannini, New insights from one case of female ejaculation. J Sex Med,Vol.8,PP.35003504,2011.

[33] B. Haylen, D. De Ridder, R. Freeman , An International Urogynecological Association (IUGA)/International Continence Society (ICS) joint report on the terminology for female pelvic floor dysfunction. Int Urogynecol,Vol.21, PP.5-26, 2010.

[34] M. Serati, A. Braga and E. Cattoni, Comments on Jha et al.: Incontinence during intercourse: Myths unravelled. IntUrogynecolJ ,Vol.23,PP.965972,2012.

[35] R. Cartwright, S. Elvy and L. Cardozo , Do women with female ejaculation have detrusor overactivity? J Sex Med,Vol.4,PP.1655-1658,2007.

[36] M. Serati, S. Salvatore, S. Uccella, A. Cromi, V. Khullar, L. Cardozo and P. Bolis, Urinary incontinence at orgasm: Relation todetrusoroveractivity and treatment efficacy. EurUrol, vol,54,PP. 911-917,2008.

[37] A. El-Azab, H. Yousef, and G. Seifeldein , Coital incontinence: Relation to detrusor overactivity and stress incontinence. Neurourol Urody,Vol.30,PP.520-524, 2011. 
[38] M. Nilsson, O. Lalos, H. Lindkvist and A. Lalos, How do urinary incontinence and urgency affect women's sexual life?.ActaObstetGynecolScand ,Vol.90,pp621-628,2011.

[39] S. Leiblum, R. Hayes , R. Wanser, J. Nelson, Vaginal dryness: a comparison of prevalence and interventions in 11 countries. J Sex Med,Vol. 6,PP.24252433,2009.

[40] R. Mota, Female urinary incontinence and sexuality. IntBraz J Urol,Vol.43,PP.20-28, 2017 A. Gilliland, Women's experiences of female ejaculation. Sex Cult, Vol.13,PP. 121-134, 2009.

[41]S. Moalem and J. Reidenberg, Does female ejaculation serve an antimicrobial purpose?

.MedHypotheses,Vol.73,PP.1069-1071, 2009.

[42] C.A. Darling, J.S. Davidson, C. ConwayWelch , Female ejaculation: perceived origins, the Grafenberg spot/area, and sexual responsiveness. Arch Sex Behav,Vol.,19,PP.29-47,1990.

[43] S. Kratochvíl, Orgasmic expulsions in women. ČeskPsychiatr, Vol.90 (2),PP. 71$77,1994$.

[44] W. Masters, V. Johnson, R. Kolodney , On sex and human loving. Boston, BA: Little, Brown and Company, 1988.
[45] G. Gravina, F. Brandetti, P. Martini, E. Carosa, S.M. Di Stasi, S. Morano, A. Lenzi, E.A. Jannini ,Measurement of the thickness of the urethrovaginal space in women with or without vaginal orgasm. J Sex Med,Vol.5,PP.610-618,2008.

[46] [46] A. Elnashar and R. Abdelhady, The impact of female genital cutting on health of newly married women.Int $J$ GynecolObst, Vol. 97(3),PP.238-4, 2007.

[47] [47] Z. Ibrahim, M. Ahmed and W. Sayed, Prevalence and risk factors for female sexual dysfunction among Egyptian women. Arch GynecolObstet,Vol.287(6),PP.117380,2013. [48] B. Bullough, M. David, B.Whipple, J. Dixon, E. R. Allgeier, K.C. Drury, Subjective reports of female orgasmic expulsion of fluid. Nurse Pract ,Vol.9,PP.55-59,1984.

[48] [49] J.K. Davidson, C.A. Darling, C. Conway-Welch, The role of the Grafenberg Spot and female ejaculation in the female orgasmic response: an empirical analysis. J Sex Marital Ther ,Vol.15,pp102-120,1989.

[49] [50] I.Younis, F. El-Esawy and R. AbdelMohsen, Is female orgasm an earthmoving experience: an Egyptian experience. Hum Andro ,Vol.5,PP.3744,20 . 
